УАK (342:35):174

ББК $67.401 .02+87.754$

DOI 10.22394/1682-2358-2021-2-32-38

A.A. Samorukov, Candidate of Sciences (Pedagogies), Docent of the Public Administration Department, Orenburg State University

\section{ETHICAL REGULATION OF THE PUBLIC SERVANTS CONDUCT}

The concept of "ethics of public service" is specified. Moral principles of public servants' activities are considered. A mechanism for effective support and control of ethical principles, as well as an ethical infrastructure of public administration is proposed.

Key words and word-combinations: ethics of public service, ethical regulation of employees' behavior, ethical infrastructure.
А.А. Саморуков, кандидат педагогических наук, доцент кафедрь государственного и муниципального управления Оренбургского государсmbенного yниверситета (email: 57samor@mail.ru) \section{ПОВЕАЕНИЯ ГОСУААРСТВЕННЫХ САУЖАЩИХ}

ЭТИЧЕСКОЕ РЕГУАИРОВАНИЕ

Аннотация. Конкретизируется понятие «этика государственной службы». Рассматриваются нравственные принципы деятельности государственных служащих. Предлагается механизм эффективной поддержки и контроля этических принципов, этическая инфраструктура государственного управления.

Ключевые слова и словосочетания: этика государственной службы, этическое регулирование поведения служащих, этическая инфраструктура.

B

последнее время в России отмечается рост общественных ожиданий и уровень требований, обращенных к госуАарственной службе, а также определенное падение уровня доверия и уважения к государству как к институту власти. В подобных обстоятельствах возрастает потребность подАержания этических норм и стандартов поведения государственных служащих.

Государственная служба была и остается профессией особой. Аیя полноценного выполнения такой работы нужен опредеменный мичностный тип исполнителя, по утверждению М. Вебера, «государствен- 
ная служба - это призвание» [1]. Служение государству - это своего рода этическая система. Она программирует государственных служащих на соблюдение моральных норм и определяет комплекс морально-нравственных ценностей. Профессионализм государственной службы неразрывно связан с нравственными качествами служащего.

Понятие этики государственной службы определяется компяексом морально-нравственных норм и представцяет характер соџиальных отношений на государственной службе [2]. Это прежде всего нормы, правика, принџипы морального поведения домжностного циџа в его взаимоотношениях с обществом и государством. Служебное поведение государственных скужащих регулируется комплексом нравственных принщипов:

- установленные нормы, опредемяющие нравственную сущность Аолжностного мица;

- систему норм, предъявмяемых государством к определению отношений должностного Аиџа с гражданским обществом;

- перечень правиц и ценностей, которые составцяют эффективность государственной службы [3] .

К сожалению, ни нормы служебной деятельности, ни нравственные принципы государственных служащих не получили должного отражения в нормативных документах, хотя в действующем российском законодательстве закреплены требования к правилам скужебного поведения.

К нормативным правовым актам, вкмючающим правила этического поведения государственных гражданских служащих, можно отнести Федеральный закон от 27 июля 2004 г. № 79-Ф3 «О государственной гражАанской службе Российской Федерации» [4], Федеральный закон от 25 декабря 2008 г. № 273-Ф3 «О противодействии коррупщии» [5], Указ Президента РФ от 12 августа 2002 г. № 885 «Об утвержАении общих принщипов служебного поведения государственных служащих» [6] .

Нормативно-правовые положения, приведенные в этих документах, регламентируют вопросы служебного поведения государственных гражАанских служащих, включая разрешение проблем в сфере конфликта интересов на гражданской службе, а также неукоснительное выполнение всеми служащими установленных ограничений и запретов в практической деятельности органов государственной власти.

При этом важная роль отводится этическому фактору, который содержит определенные моральные ценности (правдивость, законопослушность, ответственность за государственное дело, высокий профессионализм, справеАливость, политический нейтралитет, высокая заряженность на успех и эффективность) - основополагающий компонент административной этики государственных служащих и предпосылку организаџионной культуры, и нравственные принципы деятельности государственных служащих.

Приниип служения государству и обществу - один из основных принципов поведения государственных служащих, призывающих к добросовестному служению Отечеству и российскому народу. 
Приниип законности требует от всех государственных служащих строгого выполнения российских законов. Правовые нормы и правовые акты Аолжны быть наполнены нравственным смыслом и нравственной ценностью, а каждый закон соответствовац нормам морали. Несоблюдение законов аморально дмя государственных служащих, их правовой нигилизм, нерешительность в отстаивании на практике обязательств права рождают Авойственность в правоприменительной практике, что приводит в итоге к ослаблению государственной власти.

Приниип гуманизма проявияется в таких этических нормах, как признание достоинства и уважения к каждому человеку, внимание и отзывчивость к проблемам граждан, неформальная доброжелательность и искреннее желание помочь нуждающимся. Эти требования составмяют основу этических кодексов поведения государственных служащих, что соответствует профессиональному статусу должностных миџ и определяет основу Аеловой и служебной этики.

Приниип ответственности требует от каждого государственного служащего быть нравственно ответственным за организационные, управленческие и кадровые решения. Это свойственно традициям многонационамьного российского народа и вооружает управленџа государственного звена такими нормами поведения, как моральная ответственность за результаты своей служебной деятельности.

Приниип спрабедливости в государственной службе проявляется в слеАующих этических нормах: объективно оџенивать кичные и деловые качества каждого человека независимо от его материального ими имущественного положения, не допускать дискриминаџии ни при каких условиях по отношению к кому- ибо. Это напрямую связано с чувствами уважения к органам государственной власти, к ее представителям, ибо несоблюдение норм соџиальной справедливости приводит к снижению морального авторитета представителя власти. Каждый государственный служащий должен неукоснительно соблюдать в своей деятельности принџип справеАливости, проявмяющийся в законном использовании властных полномочий, в УАОвцетворении соџиальных ожиАаний насемения и в отстаивании прав и законных интересов граждан.

Приниип лояльности определяет уважение и верность к государственности своей страны. Он предполагает придерживаться преАписаний служебного поведения и осознанно выполнять каждым государственным служашим правила и нормы служебного поведения. Требуется, чтобы все служащие поддерживали своей деятельностью имидж органов государс-

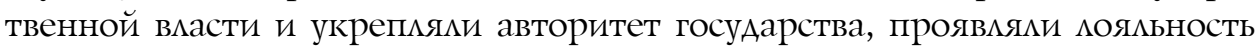
к институтам государственной власти, установленному политическому строю, гражданам.

Приниип похитической нейтральности предполагает исключить в государственно-служебных отношениях политическую борьбу за власть в

\section{Bulletin of the Volga Region Institute of Administration - 2021. Vol. 21. № 2}


государстве, ибо государственная служба призвана находиться на страже общегосударственных интересов. Необходимо исключить из служебной деятельности государственных служащих вопросы политической идеологии, политической борьбы партийных группировок, подрывающих устои законной государственной власти в стране.

Приниип честности и откриттости в современных условиях подразумевает борьбу с особо опасными и позорными явлениями - коррупџией и бюрократизмом. Отсутствие открытости и прозрачности в деятельности современной власти создают условия Аля развития коррупџии, безнаказанности, что приводит к снижению и подрыву авторитета вцасти, создает угрозу потери конституционных ценностей государства, ведет к уничтожению веры граждан в предназначение общенародного государства.

Принимаемые государством комплексы организационных и правовых мер по снижению коррупционных составцяющих на государственной службе, к сожалению, пока не привели к существенным положительным результатам на практике. В связи с этим возникает необходимость внеАрения антикоррупџионных стандартов поведения государственных скужащих, которые будут способствовать повышению качества служебной Аеятельности чиновников на основе усвоения ими комплекса знаний и умений при урегулировании возможных антикоррупционных ситуаций и закрепцении ими правовых и морально-этических норм в своей деятельности. В настоящее время этому проџессу мешает отсутствие в системе органов государственной власти нормативно-правового регулирования четких дефиниций правоотношений на региональном уровне, что тормозит реализацию новых инициатив в области правоприменения. Аанная проблема не может быть решена без внеАрения единых требований, которые определяют содержание региональных антикоррупционных стандартов на федеральном уровне.

Нравственные принципы государственной службы - это совокупность норм, которые выражают требования государства и общества к нравственной сущности государственной службы, к характеру отношений служащего с государством, обществом и Аругими служащими. Важно сформировать так называемый «этический компас», который объединяет три существенные ценности: справедливость, уважение достоинства человека и помощь, назначение которых состоит реализаџии ценностных ориентиров в государственной службе.

Аля защиты нравственных принщипов служащих необходима выработка механизма эффективной поддержки и контромя этических принџипов государственных и мунищипальных служащих - принятие этического коАекса.

23 лекабря 2010 г. на заседании Президиума Совета при Президенте РФ по противодействию коррупции был одобрен Типовой кодекс этики и служебного поведения государственных служащих Российской Федерации и 
мунищипальных служащих [7]. Отметим, что этот документ не содержкал новых предписаний, объединив ужке существующие этические нормы, предусмотренные упомянутыми федеральными законами и Указом Президента РФ.

В 2011 г. в федеральных органах государственной власти, а также в органах государственной власти субъектов РФ была проведена работа по утверждению кодексов этики по образцу Типового кодекса (приказ Министерства юстиции РФ от 23 марта 2011 г. № 93 «Об утверждении Кодекса этики и служебного поведения федеральных государственных гражданских служащих Минюста России и его территориальных органов» (далее - Кодекс этики Минюста России) [8] ; приказ Министерства образования и науки Российской Федерации от 22 июня 2011 г. № 2047 «Об утверждении Кодекса этики и служебного поведения федеральных государственных гражданских служащих Министерства образования и науки Российской Федерации» [9]; постановление Правительства Оренбургской области от 28 ноября 2016 г. № 899-п «Об утвержкении плана мероприятий («дорожной карты») по реализации основных направлений развития государственной гражданской скужбы Оренбургской области на 2016-2018 годы» [10] .

В данных нормативных актах не прописаны особенные нормы к служебному поведению государственных и муниџипальных служащих, которые отражали бы специфику региона, конкретику деятельности служащего. Нет необходимости повторять принципы и правика поведения гражданских служащих, которые закреплены в нормах основного Закона о государственной гражданской службе, а также в требованиях Указа о принципах служебного поведения. Общепринятые требования моральноэтического характера: недопущение грубости и пренебрежительного тона в общении; вежливость, Аоброжелательность и уважительность к гражданам; неформальный интерес к запросам и внимательность к проблемам каждого посетитемя; соблюдение норм служебно-делового этикета. Все это представмяет собой этические правияа служебного поведения государственного гражданского служащего.

Указанные этические кодексы формально дублируют содержание Типового кодекса и не вносят новизны. Рекомендательный характер их применения предполагает, что они не станут основой формирования нравственного обцика государственного и муниципального служащего, не будут выполняться в заявленном объеме [11].

В механизм практической поддержки необходимо внедрять, по опыту Аругих стран, советников, работа которых сходна с деятельностью омбудсменов. К этим сотрудникам обрашаются за доверительной и конфиденциальной консультаџией Аля решения конфмиктов интересов и проблем этического характера.

Механизм контроля включает в себя обязательное требование декларирования доходов государственного и муниципального служащего, уведомление о вероятности конфликта интересов, ограничительные меры на

36 Bulletin of the Volga Region Institute of Administration - 2021. Vol. 21. № 2 
Аальнейшее трудоустройство чиновника после ухода с государственной службы.

К механизму поддержки этических принципов относится понятие служебной репутации, которое подразумевает наличие морального авторитета у сотрудника. В качестве механизма поддержки этических принципов служебная репутация закрепляет за служащим (комлективом предприятия, организации, учреждения) статус нравственного авторитета, который формируется высоконравственной жизненной позицией и моральным поведением человека, что опредемяет положительный предполагаемый характер его действий в дальнейшем. САужебная репутация - это один из основополагающих компонентов механизма эффективной поддержки и контроля этических принџипов служащих.

Создание этической инфраструктуры профессиональных организаций государственных служащих предполагает включение в нее структурных подразделений организации и кадрового состава, обязанности которых заключаются в обеспечении выполнения норм кодексов. Руководители всех уровней несут должностную ответственность за проведение работы с сотрудниками и гражданами по вопросам важности соблюдения морамьных стандартов и этических ценностей на государственной службе.

Итак, в настоящее время правияа этического поведения гражданских служащих отражены и на законодательном уровне, и в Указе об общих принџипах служебного поведения. ОАнако кодексы этики поведения госуАарственных служащих субъектов государственной власти, к сожалению, не могут считаться независимыми правовыми нормами и требованиями, в них отсутствует конкретизаџия этических правия поведения гражАанского служащего, нет четкого определения понятия «этика государственного служащего», что обусловлено зависимостью от законодательных формулировок.

Представляется, что Указ об общих принципах служебного поведения может явиться той правовой формой, которая закрепит правила этического поведения гражданских служащих, а также обеспечит единое и эффективное правовое регулирование поведения гражданских служащих в сфере этики служебной деятельности. В соответствующем Законе о госуАарственной гражданской службе в Российской Федерации следует преАусмотреть соответствующую отсылочную норму. Требуется учитывать Аинамику современного законотворчества при актуализации кодексов этики, что позволит при разработке единого кодекса этики для гражАанских служащих Российской Федерации избежкать избыточного законодательного нормотворчества.

\section{Библиографический список}

1. Weber M. Theory of Social and Economic Organization. N.Y., 1947.

2. Жирков Р.П., Стефаниди Л.Ю. Этика государственной службы и государственного служащего: учебное пособие. СПб., 2016. URL: http://www.iprbookshop.ru/66937.html 
3. Браташова Ю.А. Правовое регулирование этики и служебного поведения государственного гражданского служащего Российской Федерации // Административное право и процесс. 2014. № 5.

4. О государственной гражданской службе Российской Федерации: Федер. закон от 27 июля 2004 г. № 79-Ф3 [Электронный ресурс]. Доступ из СПС «Гарант».

5. О противодействии коррупции: Федер. закон от 25 дек. 2008 г. № 273-Ф3 [Электронный ресурс]. Доступ из СПС «Гарант».

6. Об утверждении общих принципов служебного поведения государственных служащих: Указ Президента РФ от 12 авг. 2002 г. № 885 [Электронный ресурс]. Доступ из СПС «Гарант».

7. Типовой кодекс этики и служебного поведения государственных служащих Российской Федерации и муниципальных служащих (одобрен решением Президиума Совета при Президенте РФ по противодействию коррупции от 23 дек. 2010 г. (протокол № 21) [Электронный ресурс]. Доступ из СПС «Гарант».

8. Об утверждении Кодекса этики и служебного поведения федеральных государственных гражданских служащих Минюста России и его территориальных органов: приказ Министерства юстиции Российской Федерации от 23 марта 2011 г. № 93 [Электронный ресурс]. Доступ из СПС «Гарант».

9. Об утверждении Кодекса этики и служебного поведения федеральных государственных гражданских служащих Министерства образования и науки Российской Федерации: приказ Министерства образования и науки Российской Федерации от 22 июня 2011 г. № 2047 [Электронный ресурс]. Доступ из СПС «Гарант».

10. Об утверждении плана мероприятий («дорожной карты») по реализации основных направлений развития государственной гражданской службы Оренбургской области на 2016-2018 годы: постановление Правительства Оренбургской области от 28 нояб. 2016 г. № 899-п [Электронный ресурс]. Доступ из СПС «Гарант».

11. Андреев M.A. Проблема этического поведения государственных и муниципальных служащих в современных нормативных документах Российской Федерации // Вестник РГГУ. 2017. № 1 (7). С. 136-144. 